\title{
EVALUATION OF PRF EFFICIENCY IN THE TREATMENT OF INFRABONY DEFECTS
}

\author{
Jana Milutinovic, Mirjana Popovska, Biljana Rusevska, \\ Milan Nacevski, Stefan Anastasovski, Marija Ivanovska-Stojanoska
}

University Clinical Centre “St. Pantelejmon”, University Ss. Cyril and Methodius, Faculty of Dentistry, Skopje, R.N. Macedonia

Corresponding author: Jana Milutinovic, University Clinical Centre "St. Pantelejmon", University Ss. Cyril and Methodius, Faculty of Dentistry, Skopje, North Macedonia, email: dr.jana@dental-art.com.

\section{ABSTRACT}

Aim: The present study aimed to investigate the effectiveness of PRF in the treatment of infrabony defects in patients with chronic periodontitis by evaluating the clinical outcome through periodontal depth, clinical attachment level at the baseline, 6 and 9 months post operatively.

Material and Methods: Sixty infrabony defects with probing depth $\geq 5 \mathrm{~mm}$ were treated. The inclusion criterion was the necessity for surgical bilateral maxillary treatment. By using split-mouth study design, each patient had one side treated with conventional flap surgery and the other side with conventional flap surgery and PRF. Clinical parameters, such as probing depth (PD) and clinical attachment lost (CAL), were recorded in both groups at baseline, 6 and 9 months post operatively.

Results: Positive effects for all clinical and radiographic parameters were evident in the group with PRF. Mean PD reduction demonstrated statistically significant greater results in the test group $(4.00 \pm 1.07 \mathrm{~mm})$ compared to the control one $(4.83 \pm 0.99 \mathrm{~mm}), \mathrm{p}=0.003$ after 9 months postoperatively. After 9 months, there were better results in the test group compared to the control group for CAL $(5.60 \pm 1.61 \mathrm{~mm}, 6.20 \pm 1.58$ $\mathrm{mm})$, but statistically not significant.

Conclusion: Additional use of PRF in the conventional surgical treatment of infrabony defects demonstrated better parameters than the open flap debridement alone.

Keywords: infrabony defects, chronic periodontitis, periodontal regeneration, periodontal surgery, PRF

\section{INTRODUCTION}

Chronic periodontitis is inflammation caused by the interaction of pathogenic microorganisms with the host, producing products that initiate a reactive inflammatory and immune response. The end result is the destruction of the extracellular matrix, causing bone resorption [1], which definitely causes luxation, migration and early tooth loss.

The main purpose of modern periodontal therapy is the regeneration of all lost periodontal tissue, including functional periodontal ligament, alveolar bone and cement.

The classic open surgical debridement of unresponsive infrabony defects of conservative treatment, removes periopathogenic bacteria as well as damaged, ulcerated, necrotized and proliferating tissue, but this intervention is insufficient for tissue regeneration of the destroyed structures. Growth factors released in response to tissue injury show 
the ability to stimulate cells present in the periodontium resulting in the proliferation and differentiation of endothelial cells, osteoblasts, chondrocytes, and fibroblasts. [2] From this aspect, platelets (Tr) are considered a natural source of growth factors, which are believed to play a vital role in the healing process of lesions after periodontal treatment. [3] Platelet rich fibrin (PRF), belongs to the second generation of platelet concentrates which has regenerative potential and application in surgical treatment of periodontal disease. [4]

In fact, PRF has attracted the attention of numerous researchers and clinicians, because of its positive clinical effects, due to the spontaneous formation of a dense three-dimensional fibrin network incorporating growth factors from $\mathrm{Tr}$ and Leu, but also from blood, such as PDGF, TGF- B1, IGF, VEGF. [5,6] These growth factors that are released continuously for 7 to 14 days locally stimulate bone cells, soft tissue and initiate angiogenesis. [7.8]

Some previous studies have shown that PRF can be used as the sole regenerative material for surgical treatment of periodontal pockets, i.e. with flap intervention $[9,10-12]$ demonstrating a reduction in periodontal pockets depth and CAL gain, but histologic studies are lacking to confirm the beneficial effect. [13] In vivo and in vitro bone matrix demineralization studies have reported effective treatment, with evident radiographic bone corrections and improvement of clinical parameters. [14, 15]

On the other hand, PRF is accepted as a supporting matrix of bone grafts when treating infrared pockets, which can also be used as a graft covering membrane. Thus PRF associated with bone grafts has an angiotropic, hemostatic and osteoconductive characteristic. This combination is ideal for achieving excellent results in the treatment of infrabony defects. [16, 17-20]

Starting from the fact that PRF contains three important aspects of regeneration, which act synergistically: three-dimensional fibrin network, autogenous cells (Leu, Tr, macrophages and neutrophils) and growth factors, this study will follow the effect of its treatment application in infrabony defects in patients with chronic periodontal disease by follow-up of PD and CAL after 6 and 9 months of treatment.

\section{MATERIALS AND METHODS}

This study belongs to the split-mouth category, which included 60 bone defects, in systemically healthy patients of both sexes, with an age range of 30-50 years. The selection of patients and intervention was made at the Clinic for Oral Diseases and Periodontology at the University Clinical Dental Centre Skopje in the period 2015-2017. The study group was formed of patients with bilateral infrabony defects that were divided into two groups, 30 defects treated with open surgical debridement (modified Widman) and application of PRF, and 30 defects treated only with open surgical debridement forming the control group.

The selection of patients was made according to inclusion and exclusion criteria. These criteria included a diagnosed and radiographically confirmed infrabony defects in distal maxilla section, with a depth of $\geq 5 \mathrm{~mm}$. The study excluded patients with platelet disorders, haemostasis and other systemic diseases, smokers, pregnant women, nursing mothers, and patients with poor oral hygiene. Patients filled out an information form and written consent for the planned surgical procedure.

\section{Preoperative phase}

Each patient was first instructed and motivated to maintain good oral hygiene. Then the dental plaque and calculus were removed by ultrasound and manually. Initial therapy was re-evaluated after 7 days. All patients were haematologically monitored preoperatively by complete blood count analysis and haemostasis.

\section{Clinical evaluation and measurements}

Clinical evaluation and measurements were made on the depth of periodontal pockets and clinical loss of attachment by the same therapist. The first measurement was done just before the intervention, 6 and 9 months after the surgery.

\section{Preparation of PRF}

The procedure began with the collection of $12 \mathrm{ml}$ of blood in test tubes without an anticoagulant just before each patient's surgery. The test tubes were then centrifuged at $3000 \mathrm{rpm}$ for 12 min with a Multifuge Heraeus centrifuge, using the Choukroun method. The tubes containing the fibrin network were returned to the operating room, where they were separated from the erythrocyte sediment and the acellular plasma. 


\section{Surgical procedure}

After anaesthesia was applied, a sulcular incision was made buccally and palatinally, followed by elevating full thickness flap to the mucogingival line. After thorough processing of the operating field with ultrasound and manually, the PRF membrane was inserted, the flap was reposed and sutured. In case of the control group, after the periodontal pockets were processed, the flap was reposed and sutured without adding PRF.

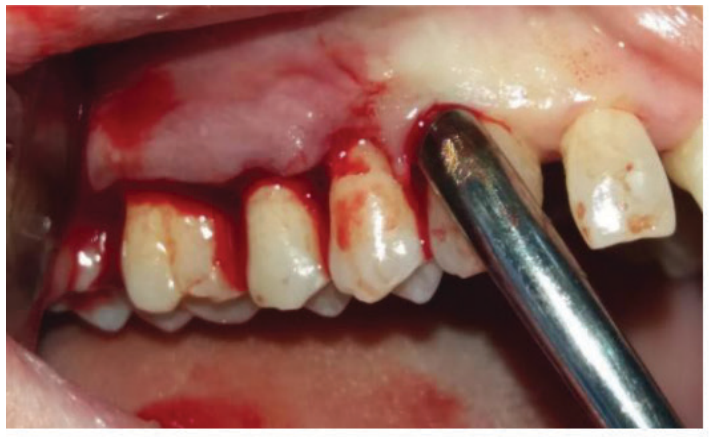

$\mathrm{a}, \mathrm{b})$

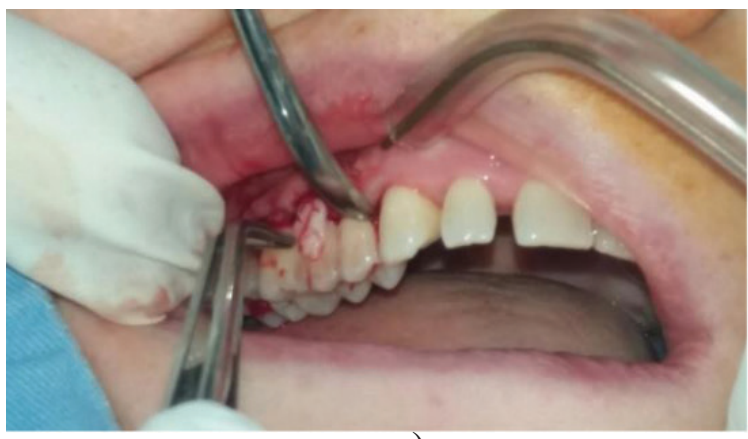

e)

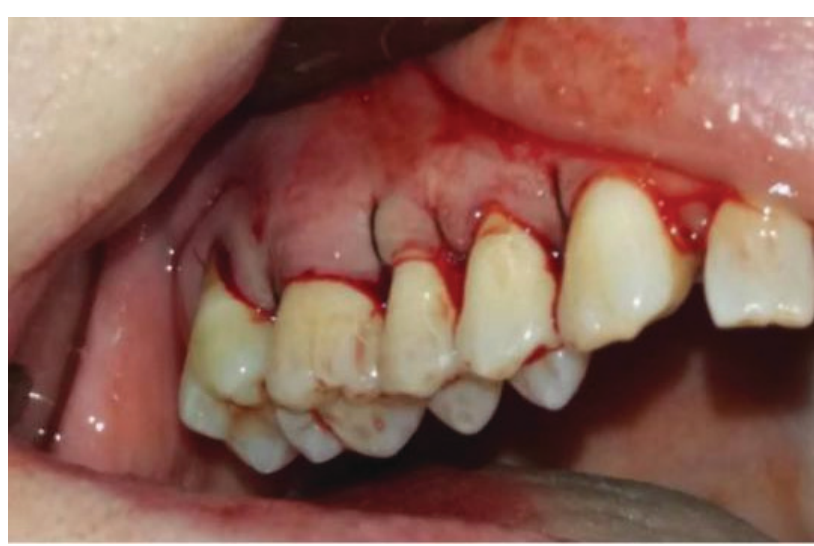

g)

\section{Post-surgical procedure}

Postoperatively, all patients were prescribed analgesics three times daily, at most 5 days as needed. Locally, patients were instructed to rinse their mouth two to three times daily with $0.12 \%$ Chexidine Gluconate (CHX) for 2 weeks. The sutures were removed after 7 days. After one week a gentle brushing with a soft toothbrush was recommended to the study participants. Control examinations were conducted at 6 and 9-month intervals in the two different treated regions. The indicated parameters were followed up again by the same therapist.

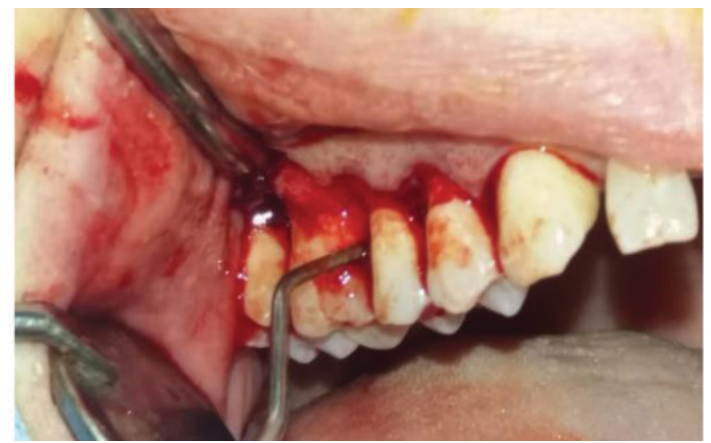

$c, d)$

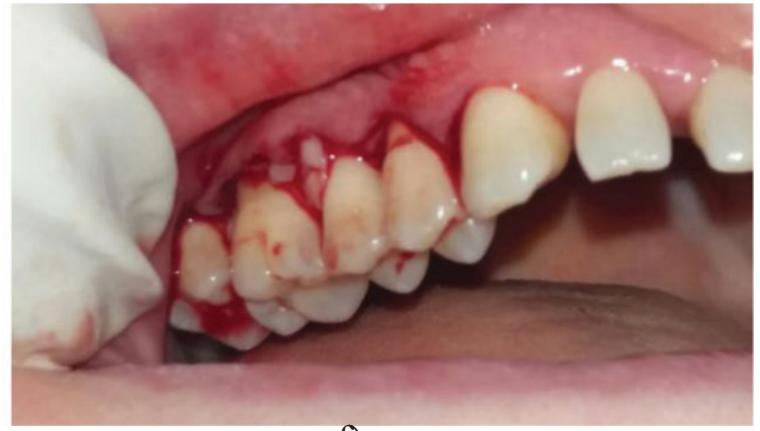

f)

Picture 1. Operational course of interventions:

a) incision;

b) lifting;

c) debridement;

d) deep curettage of periodontal pockets;

e) f) application of PRF periodontal defect;

g) suturing phase 
Data analysis was performed in the statistical program STATISTICA

\section{RESULTS}

The findings indicated that the value of PD defect after 9 months of treatment had significantly better results in the study group $(4.00 \pm 1.07$ $\mathrm{mm})$ than the control group $(4.83 \pm 0.99 \mathrm{~mm}), \mathrm{p}$ $=0.003$, table 1 and 2 .

Table 1. Difference in values of periodontal pocket depth index (PD) at baseline, after 6 and 9 months of incision surgery using PRF in the examined group

\begin{tabular}{ccccc}
\multicolumn{6}{c}{ Friedman ANOVA Chi Sqr. $(\mathrm{N}=30, \mathrm{df}=2)=47.64 ; \mathrm{p}=0,000$} \\
\hline Parameter & $\begin{array}{c}\text { Average } \\
\text { Rank }\end{array}$ & $\begin{array}{c}\text { Sum of } \\
\text { Ranks }\end{array}$ & Mean & Std. Dev. \\
\hline \hline PD baseline & 2.82 & 84.50 & 5.83 & 1.29 \\
\hline \hline PD after 6 months & 1.95 & 58.50 & 4.77 & 1.25 \\
\hline \hline PD after 9 months & 1.23 & 37.00 & 4.00 & 1.02 \\
\hline
\end{tabular}

Table 2. Difference in PD values at baseline, at 6 and 9 months post-operatively without PRF in the control group

\begin{tabular}{ccccc}
\multicolumn{5}{c}{ Friedman ANOVA Chi Sqr. $(\mathrm{N}=30, \mathrm{df}=2)=30.10 ; \mathrm{p}=0.000$} \\
\hline $\begin{array}{c}\text { Average } \\
\text { Rank }\end{array}$ & $\begin{array}{c}\text { Sum of } \\
\text { Ranks }\end{array}$ & Mean & Std. Dev. \\
\hline \hline PD baseline & 2.57 & 77.00 & 5.73 & 1.08 \\
\hline PD after 6 months & 1.87 & 56.00 & 5.23 & 1.01 \\
\hline \hline PD after 9 months & 1.57 & 47.00 & 4.83 & 0.99 \\
\hline
\end{tabular}

Although not statistically significant, better clinical findings were evident in the PRF-treated group than in the control, for CAL $(5.60 \pm 1.61 \mathrm{~mm}$, $6.20 \pm 1.58 \mathrm{~mm}$ ) after 9 months, Tables 3 and 4 .

Table 3. Difference in CAL values at baseline and at 6 and 9 months after incision surgery with PRF application in the study group

\begin{tabular}{lcccc}
\multicolumn{5}{c}{ Friedman ANOVA Chi Sqr. $(\mathrm{N}=30, \mathrm{df}=2)=44.67: \mathrm{p}=0.000$} \\
\hline $\begin{array}{c}\text { Avcrage } \\
\text { Rank }\end{array}$ & $\begin{array}{c}\text { Sum of } \\
\text { Ranks }\end{array}$ & Mean & Std. Dev. \\
\hline Parameter & 2.78 & 83.50 & 7.47 & 1.74 \\
\hline \hline CAL 6 6 moneline & 1.95 & 58.50 & 6.37 & 1.56 \\
\hline \hline CAL 9 months follow-up & 1.27 & 38.00 & 5.60 & 1.61 \\
\hline
\end{tabular}

Table 4. Difference in CAL values at baseline, at 6 and 9 months after incision surgery without PRF application in control group

\begin{tabular}{lcccc}
\multicolumn{5}{c}{ Friedman ANOVA Chi Sqr. $(\mathrm{N}=30, \mathrm{df}=2)=26.45 ; \mathrm{p}=0.000$} \\
\hline \hline Parameter & $\begin{array}{r}\text { Average } \\
\text { Rank }\end{array}$ & $\begin{array}{c}\text { Sum of } \\
\text { Ranks }\end{array}$ & Mean & Std. Dev. \\
\hline \hline CAL baseline & 2.55 & 76.50 & 7.30 & 1.64 \\
\hline \hline CAL 6 months follow-up & 1.85 & 55.50 & 6.63 & 1.35 \\
\hline \hline CAL 6 months follow-up & 1.60 & 48.00 & 6.20 & 1.58
\end{tabular}

There is an evident difference between the values of PD and CAL in the study and control groups of patients at 9 months follow-up - Tables 5 and 6.

Table 5. Difference in PD values between the study and the control group after 9 months of intervention

\begin{tabular}{|c|c|c|c|c|c|c|c|}
\hline Parameter & $\begin{array}{l}\text { Rank Sum } \\
\text { Study group }\end{array}$ & $\begin{array}{l}\text { Rank Sum } \\
\text { Control group }\end{array}$ & $\mathrm{U}$ & $\mathrm{Z}$ & $\mathrm{p}$-level & $\begin{array}{c}\mathrm{N} \\
\text { Study group }\end{array}$ & $\begin{array}{c}\mathrm{N} \\
\text { Control group } \\
\end{array}$ \\
\hline PD after 9 months & 711.50 & 1118.50 & 246.50 & $-3,01$ & 0,003 & 30 & 30 \\
\hline \multicolumn{8}{|c|}{$\begin{array}{l}\text { Table 6. Difference in CAL values between the study group and the control group after } 9 \text { months of } \\
\text { intervention. }\end{array}$} \\
\hline Parameter & $\begin{array}{l}\text { Rank Sum } \\
\text { Study group }\end{array}$ & $\begin{array}{l}\text { Rank Sum } \\
\text { Control group }\end{array}$ & $\mathrm{U}$ & Z & p-level & $\begin{array}{c}\mathrm{N} \\
\text { Study group }\end{array}$ & $\begin{array}{c}\mathrm{N} \\
\text { Control group }\end{array}$ \\
\hline CAL after 9 months & 832.00 & 998.00 & 367.00 & -1.23 & 0.22 & 30 & 30 \\
\hline
\end{tabular}

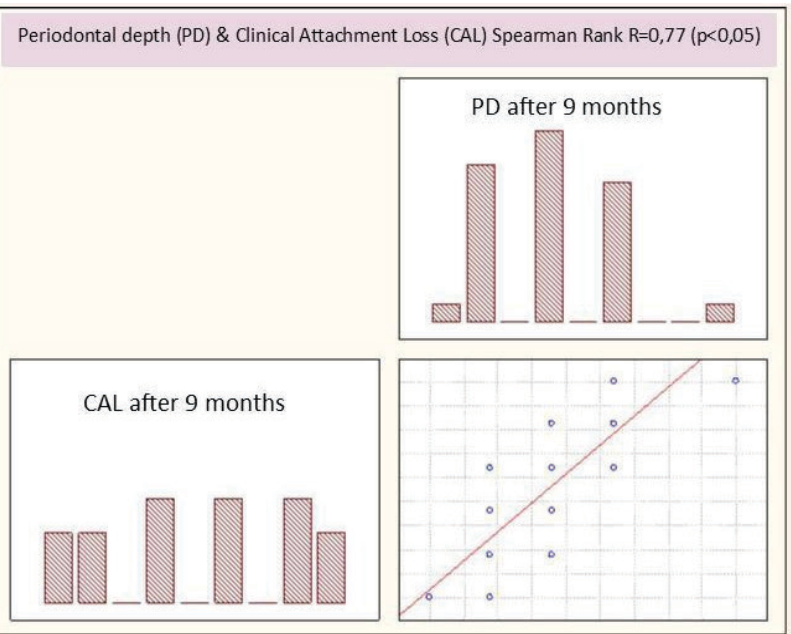

Graph 1. Correlation between $P D$ and $C A L$ after 9 months of PRF surgery

There is a positive correlation between the clinical finding of the group treated with surgery and PRF, compared to the group treated with surgery alone, at 6 and 9 months postoperatively. A very strong positive significant correlation was found between PD and CAL, 9 months after PRF surgery. Namely, correction of CAL is followed by better PD results. 


\section{DISCUSSION}

Periodontal pocket depth reduction and loss of clinical attachment are the most important clinical parameters showing healing results in the absence of histological analysis of soft and hard tissue. [21] In our study, we found a decrease in the PD and CAL index in the control and study groups after 6 and 9 months compared to baseline. PD in the study group varies $4.00 \pm 1.07 \mathrm{~mm}$, the index of clinical attachment loss in the study group varies in the interval $5.60 \pm 1.61 \mathrm{~mm}$. PD in the control group varies in the interval $4.83 \pm$ $0.99 \mathrm{~mm}, \mathrm{CAL}$ in the control group ranges in the interval $6.20 \pm 1.58 \mathrm{~mm}$. The value of PD after intervention with PRF is lower than the value at baseline, the difference between the values for $\mathrm{Z}=4.01$ and $\mathrm{p}<0.001(\mathrm{p}=0.000)$ is significant.

The value of PD after treatment is lower than the value at baseline, the difference between the values for $Z=3.41$ and $p<0.001(p=0.000)$ is also significant. These results show that we have fairly rapid and significant results in both groups, confirming that surgical therapy is a solid therapeutic modality in infrabony pockets over $5 \mathrm{~mm}$. PD 9 months after surgery showed lower values than baseline and after 6 months and these differences were significant at $Z=3.82$ and $p<0.001$ ( $p$ $=0.000$ ) and $Z=2.37$ and $p<0.05$ (respectively), $p=0.02)$. The value of PD 9 months after PRF surgery is lower than the value at baseline and after 6 months, where the differences are significant $\mathrm{Z}=4.62$ and $\mathrm{p}<0.001(\mathrm{p}=0.000), \mathrm{Z}=3.72$ and $\mathrm{p}<0.001(\mathrm{p}=0.000)$.

Comparatively, the results obtained 6 months after the treatment between the two groups showed that the PD value in the control group was higher than the control group, but the difference between the values for $Z=-1.71$ and $p>0.05$ ( $p$ $=0.09)$ is not significant, unlike the results after 9 months where the value of PD in the control group is higher than the control group, and the difference between the values for $Z=-3.01$ and $p<0.01(p=0.003)$ is already significant. These comparative results, obtained after 9 months, indicate that treatment with PRF gives consistent, stable results.

CAL values after 6 months after surgery were lower than the values at baseline, the difference between the values for $Z=3.27$ and $p<0.01$ $(p=0.001)$ was significant. The values after 9 months are $\mathrm{Z}=3.68$ and $\mathrm{p}<0.001(\mathrm{p}=0.000), \mathrm{Z}$ $=2.24$ and $\mathrm{p}<0.05(\mathrm{p}=0.03)$.

The value of CAL after 6 months of PRF intervention showed lower values than the value at baseline, the difference between the values for $\mathrm{Z}$ $=3.88$ and $p<0.001(p=0.000)$ is significant. The value of CAL after 9 months after PRF surgery is lower than the value at baseline and after 6 months after PRF surgery, the difference between values is significant. $Z=4.54$ and $p<0.001(p=0.000)$, $Z=3.62$ and $p<0.001(p=0.000)$. The value of CAL in the control group after 9 months of surgery was higher than the value in the examined group, but the difference between the values for $Z=-1.23$ and $p>0.01(p=0.22)$ was not significant.

To date, there are more than 10 published relevant randomized trials in which PRF is used as regenerative therapy of infrabony defects, either alone or in combination with bone grafts. [16]

Thorat et al. obtain a significant statistical difference in the results of PD and CAL after 9 months $(p<0.01)$ in the control and the study group. But in the group treated with PRF, they received a greater reduction in $\mathrm{PD}(4.56-0.37)$ and CAL (3.69 -0.44). Similar results show Ajwani et al. [12] Their results showed a significant difference $(p=0.005)$ between PD and CAL scores at baseline and after 9 months, in favour of the PRF-treated group.

These results are in line with the results obtained by Sharma et al. [22] who receive a vertical CAL increase of $2.33 \mathrm{~mm}$ in the PRF group, compared to $1.28 \mathrm{~mm}$ in the control group with only 9 months of the surgery. Rosama et al. [23] also received a significant positive result by decreasing CAL after one year by about $3.36 \pm 0.38 \mathrm{~mm}$ compared to the control group. Regarding PD, the difference between the groups ranges from 2.29 $\pm 0.3 \mathrm{~mm}$ for the experimental group. Pradeep et al. 9 also received a significant reduction in PD $(3.77 \pm 1.19)$ after 9 months compared to the group treated with open flap debridement surgery only. Their findings for CAL, like our results, show better results in both groups after 9 months, with the PRF- treated group being better, but without a significant difference compared to the control group. Bajaj et al. [24] also received a decrease in PD $(4.291 \pm .04 \mathrm{~mm})$ compared to the control group $(1.58 \pm 1.02)$ and a CAL gain in the study $(2.87 \mathrm{~mm})$ compared to the control group $(1.37$ mm) 9 months post operatively, but without statistically significant values. The reason for this result may be true regeneration via a new attachment in 
the PRF-treated group, and in the control group, healing through repair and improved CAL are the result of long epithelial adhesion. [25]

\section{CONCLUSIONS}

Additional use of PRF in the conventional surgical treatment of infrabony defects demonstrated decrease in PD and CAL values recorded at 9 months compared to those at 6 months and at the baseline. However, multicentre randomized, controlled clinical trials will be required to prove PRF's clinical and radiographical effects over bone regeneration on the long run.

\section{REFERENCES}

1. Kirkwood KL, Cirelli JA, Rogers JE, Giannobile WV. Novel host response therapeutic approaches to treatperiodontal diseases. Periodontol 2000 2007; 43: 294-315.

2. Wang ZS, Feng ZH, Wu GF, Bai SZ, Dong Y, Chen FM, et al. The use of platelet-rich fibrin combined with periodontal ligament and jaw bone mesenchymal stem cell sheets for periodontal tissue engineering. Sci Rep. 2016; 6: 28126.

3. Kim TH, Kim SH, Sandor GK, Kim YD. Comparison of platelet-rich plasma (PRP), plateletrich fibrin (PRF), and concentrated growth factor (CGF) in rabbit-skull defect healing. Arch Oral Biol. 2014; 59: 550-

4. Choukroun J, Adda F, Schoeffler C, Vervelle A. PRF: An opportunity in perio-implantology. Implantodontie. 2001; 42: 55-62.

5. Dohan Ehrenfest DM, Choukroun J, Diss A, Dohan SL, Dohan AJ, Mouhyi J, et al. Platelet-rich fibrin (PRF): A second-generation platelet concentrate. Part III: Leucocyte activation: a new feature for platelet concentrates? Oral Surg Oral Med Oral Pathol Oral Radiol Endod. 2006; 101: 51-5.

6. Dohan Ehrenfest DM, Choukroun J, Diss A, Dohan SL, Dohan AJ, Mouhyi J, et al. Platelet-rich fibrin (PRF): A second-generation platelet concentrate. Part II: Platelet-related biologic features. Oral Surg Oral Med Oral Pathol Oral Radiol Endod. 2006; 101: 45-50.

7. Desai, C.B., et al.Use of Platelet-Rich Fibrin over Skin Wounds: Modified Secondary Intention Healing. J Cutan Aesthet Surg, 2013. 6(1): p. $35-7$.
8. Martinez CE, Smith PC, Palma VA. The influence of platelet-derived products on angiogenesis and tissue repair: A concise update. Front Physiol. 2015; 6: 290.

9. Pradeep AR, Rao NS, Agarwal E, Bajaj P, Kumari M, Naik SB. Comparative evaluation of autologous platelet-rich fibrin and platelet-rich plasma in the treatment of 3 wall intrabony defects in chronic periodontitis: A randomized controlled clinical trial. J Periodontol. 2012; 83: 1499-1507.

10. Mathur A, Bains VK, Gupta V, Jhingran R, Singh GP. Evaluation of intrabony defects treated with platelet-rich fibrin or autogenous bone graft: A comparative analysis. Eur J Dent. 2015; 9: $100-8$.

11. Gupta SJ, Jhingran R, Gupta V, Bains VK, Madan R, Rizvi I. Efficacy of platelet-rich fibrin vs. enamel matrix derivative in the treatment of periodontal intrabony defects: A clinical and cone beam computed tomography study. J Int Acad Periodontol. 2014; 16: 86-96.

12. Ajwani H, Shetty S, Gopalakrishnan D, Kathariya R, Kulloli A, Dolas RS, et al. Comparative evaluation of platelet-rich fibrin biomaterial and open flap debridement in the treatment of two and three wall intrabony defects. J Int Oral Health. 2015; 7: 32-7.

13. Dangaria SJ, Ito Y, Walker C, Druzinsky R, Luan $\mathrm{X}$, Diekwisch TG. Extracellular matrix-mediated differentiation of periodontal progenitor cells. Differentiation 2009; 78: 79-90.

14. Peker E, Karaca IR, Yildirim B. Experimental evaluation of the effectiveness of demineralized bone matrix and collagenated heterologous bone grafts used alone or in combination with platelet-rich fibrin on bone healing in sinus floor augmentation. Int J Oral Maxillofac Implants. 2016; 31: e24-31.

15. Bigham AS, Dehghani SN, Shafiei Z, Nezhad ST. Xenogenic demineralized bone matrix and fresh autogenous cortical bone effects on experimental bone healing: Radiological, histopathological and biomechanical evaluation. J Orthopaed Traumatol. 2008; 9: 73-80.

16. Richard J. Miron, Giovanni Zucchelli, Michael A. Pikos, Maurice Salama, Samuel Lee, Vincent Guillemette, Masako Fujioka-Kobayashi, Mark Bishara, Yufeng Zhang, Hom-Lay Wang, Fatiha Chandad, Cleopatra Nacopoulos, Alain Simonpieri, Alexandre Amir Aalam, Pietro Felice, Gilberto Sammartino, Shahram Ghanaati, Maria A Hernandez, Joseph Choukroun. Use of plateletrich fibrin inregenerative dentistry: asystematic review.Clin Oral Invest 2017.

17. Marco Del Corso, Alain Vervelle, Alain Simonpieri, Ryo Jimbo, Francesco Inchingolo, Gilberto Sammartino, David M. Dohan Ehrenfest. Cur- 
rent Knowledge and Perspectives for the Use of Platelet-Rich Plasma (PRP) and Platelet-Rich Fibrin (PRF) in Oral and Maxillofacial Surgery Part 1: Periodontal and Dentoalveolar Surgery. Current Pharmaceutical Biotechnology, 2012, 13, 1207-1230 1207 1873-4316

18. Camargo, P.M.; Lekovic, V.; Weinlaender, M.; Vasilic, N.; Madzarevic, M.; Kenney, E.B. A reentry study on the use of bovine porous bone mineral, GTR, and platelet-rich plasma in the regenerative treatment of intrabony defects in humans. Int. J. PeriodonticsRestorative Dent., 2005, 25(1), 49-59.

19. Lekovic, V.; Camargo, P.M.; Weinlaender, M.; Vasilic, N.; Aleksic, Z.; Kenney, E.B. Effectiveness of a combination of plateletrich plasma, bovine porous bone mineral and guided tissue regeneration in the treatment of mandibular grade II molar furcations in humans. J. Clin. Periodontol., 2003, 30(8), 746-751.

20. Camargo, P.M.; Lekovic, V.; Weinlaender, M.; Vasilic, N.; Madzarevic, M.; Kenney, E.B. Platelet-rich plasma and bovine porous bone mineral combined with guided tissue regeneration in the treatment of intrabony defects in humans. J. Periodontal Res.,2002, 37(4), 300-306.
21. Yu-Chao Chang, Kuo-Chin Wu, Jiing-Huei Zhao. Clinical application of platelet-rich fibrin as the solegrafting material in periodontal intrabony defects. Journa of Dental Science 2011; 6 . 181-182.

22. Sharma A, Pradeep AR. Treatment of 3-wall intrabony defects in patients with chronic periodontitis with autologous platelet-rich fibrin: a randomized controlled clinical trial.J Periodontol. 2011 Dec; 82(12): 1705-12.

23. Rosamma Joseph, Arun Raghunatha, Nitin Sharmab. Clinical effectiveness of autologous platelet rich fibrin in the management of infrabony periodontal defects. Singapore Dental Journal 33(2012) 5-12.

24. Bajaj P, Pradeep AR, Agarwal E, Rao NS. Comparative evaluation of autologous platelet-rich fibrin and platelet-rich plasma in the treatment of mandibular degree II furcation defects: a randomized controlled clinical trial. J Periodont Res. 2013; 48 (5): 541-676.

25. Yang LC, Hu SW, Yan M, Yang JJ, Tsou SH, Lin YY. Antimicrobial activity of platelet-rich plasma and other plasma preparations against periodontal pathogens. J Periodontol. 2015; 86: 310-8. 


\section{Резиме}

ПРОЦЕНА НА ЕФЕКТИТЕ ОД ПРИМЕНАТА НА РRF ВО ТРЕТМАНОТ НА ИНФРАКОСКЕНИТЕ ДЕФЕКТИ

\section{Јана Милутиновиќ, Мирјана Поповска, Билјана Русевска, Милан Нацевски, Стефан Анастасовски, Марија Ивановска-Стојаноска}

Универзитетски стоматолошки клинички центар „Свети Пантелејмон“, Стоматолошки факултет, Скопје, РС Македонија

Цел: Да се испита ефектот на PRF во третманот на инфракоскените дефекти кај пациенти со хронична пародонтопатија преку процена на клиничкиот статус пред хируршка интервенција, шест и девет месеци по интервенцијата.

Материјал и метод: Третирани се шеесет инфракоскени дефекти со длабочина на пародонталните џебови (PD) $\geq 5 \mathrm{~mm}$. Во испитувањето се вклучени и дијагностицирани PD во горна вилица, кои се рендгенографски потврдени билатерално странично со длабочина од $\geq 5$ $\mathrm{mm}$. Користејќи дизајн на студија split-mouth, кај секој пациент едната страна е третирана со конвенционална flap-интервенција, а другата е третирана со flap-оперативна метода и дополнување со PRF. Клиничките параметри, како што се PD и ниво на клинички атачмен (CAL), ce одредувани во двете групи пред интервенцијата и шест и девет месеци по неа.

Резултати: Позитивни тераписки ефекти се евидентни во групата третирана комбинирано (flap + PRF). Наодите укажаа дека вредностите на PD по девет месеци од третманот има значајно подобри резултати $(4,00 \pm 1,07 \mathrm{~mm})$ во однос на контролната $(4,83 \pm 0,99 \mathrm{~mm}), \mathrm{p}=0,003$. Иако без статистичко значење, евидентни се подобри клинички наоди кај групата третирана со PRF во однос на контролната, за CAL $(5,60 \pm 1,61 \mathrm{~mm}, 6,20 \pm 1,58 \mathrm{~mm})$ по девет месеци .

Заклучок: Дополнителната примена на PRF во конвенционалниот хируршки третман на инфракоскени дефекти покажа подобар клинички резултат во однос на стандардно применуваната флап-интервенција.

Клучни зборови: инфракоскени дефекти, хронична пародонтопатија, пародонтална регенерација, пародонтална хирургија 